\title{
Proinflammatory MG-63 cells response infection with Enterococcus faecalis cps2 evaluated by the expression of TLR-2, IL-1 $\beta$, and iNOS mRNA
}

\author{
Boy M. Bachtiar* and Endang W. Bachtiar
}

\begin{abstract}
Objective: We have previously demonstrated that unencapsulated Enterococcus faecalis cps 2 inhibits biofilm formation of Candida albicans, a fungus commonly found with E. faecalis in periapical lesion. In this study, we compared encapsulated and unencapsulated E. faecalis cps2 strains relationship with osteoblastic (MG-63) cells, whereas E. faecalis ATCC 29212 were used as a reference strain.

Results: The binding capacity of E. faecalis to MG-63 cells as shown by each tested strain was comparable, but the unencapsulated strain was less invasive compared to the encapsulated and the reference strains. Moreover, quantitative real time-PCR (qPCR) results showed that infecting unencapsulated $E$. faecalis cps 2 is a stronger stimulator for toll like receptor 2 (TLR2) and interleukin-1 $\beta$ (IL-1 $\beta$ ) mRNAs, but not for inducible nitric oxide synthase (iNOS) mRNA in osteoblastic cells. In conclusion, the performance of unencapsulated $E$. faecalis cps 2 when the bacterium interacts with osteoblastic cells is quite different from that of encapsulated E. faecalis cps 2 and reference strains. It appears that the unencapsulated strain might contribute to the persistence of the periapical inflammatory response, depending on down-regulation of iNOS mRNA expression.
\end{abstract}

Keywords: Encapsulated and unencapsulated E. faecalis cps2, MG-63, TLR-2, IL-1 $\beta$ and iNOS

\section{Introduction}

From all known as Enterococcus spp., Enterococcus faecalis has been studied for its involvement in periapical inflammation [1,2]. Among its serotypes, especially serotype $C$ that belong to cps 2 genotype, are virulent bacteria, and their capsular polysaccharides are responsible for inflammatory responses $[3,4]$. However, there is a discrepant opinion regarding the possible role of E. faecalis cps2 in the pathogenesis of periapical inflammation. A report by Pinheiro [5] shows that the most common isolate that found in infected root canal with periapical lesion is E. faecalis cps1, thus unencapsulated strain [3]. This report contradicts our results, where the E. faecalis cps2 was found to be the

*Correspondence: boybachtiar@gmail.com; boy_mb@ui.ac.id Department of Oral Biology and Oral Science Research Center, Faculty of Dentistry, Universitas Indonesia, JI. Salemba Raya 4, Jakarta 10430, Indonesia dominant bacterium from endodontic patients, and it consists of two different strains [6]. Both isolates possess all the cps2 genes [7], but the insertion sequence 6770, detected by qPCR [7], may influence the translation of some of the capsule genes and the synthesis of the polysaccharide. How these differences affect phenotype properties of E. faecalis serotype $\mathrm{C}$ oral isolates when the bacterium interacts with bone-forming cells, remains to be elucidated.

We previously examined the antagonistic interaction between unencapsulated E. faecalis cps2 and Candida albicans [8], a fungus frequently found together with $E$. faecalis in periapical lesion [9]. The present study aimed to examine the in vitro ability of encapsulated and unencapsulated E. faecalis cps2 to infect human MG-63 osteosarcoma cell lines. We also studied the expression of certain inflammatory response-related genes (TLR-2, IL-1 $\beta$, and iNOS), when the bacteria interact with MG-63 cells. 


\section{Main text}

\section{Methods}

Adhesion and internalization by MG-63 cells of three E. facials strains

Enterococcus faecalis strains used in this study were E. faecalis cps2 oral isolates. These strains were isolated from endodontic patients in our previous study [6], and were separated in encapsulated and unencapsulated strains using qPCR (Fig. 1). The bacteria had been previously categorized as highly biofilm formation strains [6], while the reference strain (E. faecalis ATCC 29212) was included in parallel for the comparison experiment.

The bacteria were maintained and prepared for experiment as previously reported [8], while a modified gentamicin protection assay was performed to study bacteria-host interactions [10]. MG-63 cells were used as host cell in this study and were cultured in DMEM and supplemented with 10\% FBS and penicillin, streptomycin, and glutamine. The cells were further stimulated with different E. faecalis strains at a Multiplicity of Infection (MOI) of 1000. At different times from the post-infection (3 and $12 \mathrm{~h}$ ), the RNA from infected MG-63 cells were extracted for mRNA transcription analysis of the targeted inflammatory-related genes. The assays were conducted in duplicate and repeated independently three times, while cells without added E. faecalis were used as control. For statistical analysis, Student's $t$ test was performed with Microsoft Excel software. A p value of $<0.05$ was defined significant.

\section{Quantitation of TLR2, IL-1 $\beta$, and iNOS transcripts from MG-63 cells by real-time $P C R$}

After infection, the total cellular RNA was extracted using Trizol reagent (Invitrogen) followed by reverse transcription using the TaqMan Reverse Transcription kit (Applied Biosystems). The resulting cDNA was amplified by qPCR with specific primers as shown in Table 1. The qPCR analysis was performed in ABI StepOnePlus Real-Time PCR Systems with SYBR Green PCR master mix (Applied Biosystems) according to manufacturer's protocol. The PCR conditions were set as follow pre-denaturation at $95{ }^{\circ} \mathrm{C}$ for $5 \mathrm{~min}$ followed by 40 cycles of $95{ }^{\circ} \mathrm{C}$ for $10 \mathrm{~s}, 60{ }^{\circ} \mathrm{C}$ for $30 \mathrm{~s}$, and $72{ }^{\circ} \mathrm{C}$ for $30 \mathrm{~s}$, and a final extension at $72{ }^{\circ} \mathrm{C}$ for $5 \mathrm{~min}$. The melt curve profile was set as follow $95^{\circ} \mathrm{C}$ for $15 \mathrm{~s}, 60{ }^{\circ} \mathrm{C}$ for $60 \mathrm{~s}$, and $95^{\circ} \mathrm{C}$ for $15 \mathrm{~s}$.

In this study, the target gene expression was normalized to the level of D-glyceraldehyde- 3 phosphate dehydrogenase (GAPDH), and cells without exposure to $E$. faecalis were set to be the control. The formula of fold change $2^{-\Delta \Delta \mathrm{Ct}}$ was used to analyze the mRNA expression level of targeted genes [11].

The experiment procedure was performed in triplicate for each sample and repeated two times in separated occasion. The collected data were expressed as mean standard deviation, and the mean quantitative gene expression was compared via Student's $t$ test using Microsoft Excel software. A p level of $<0.05$ was defined significant.

\section{Table 1 Primers used for real-time PCR in this study}

\begin{tabular}{|c|c|c|}
\hline Primer name & Sequences & References \\
\hline TLR2 & $\begin{array}{l}\text { Forward: 5'-ggccagcaaattacctgtgtg-3' } \\
\text { Reverse: 5'-aggcggacatcctgaacct-3' }\end{array}$ & [28] \\
\hline$\| L-1 \beta$ & $\begin{array}{l}\text { Forward: 5'-acgatgcacctgtacgatca-3' } \\
\text { Reverse: 5'-tctttcaacacgcaggacag-3' }\end{array}$ & [29] \\
\hline iNOS & $\begin{array}{l}\text { Forward: 5'-tctccgaccaccactacagcaa-3' } \\
\text { Reverse: 5'-ggggaactgggcagactcaa-3' }\end{array}$ & [30] \\
\hline GDPH & $\begin{array}{l}\text { Forward: 5'-aatggaaatcccatcaccatct-3' } \\
\text { Reverse: } 5^{\prime} \text {-cagcatcgccccacttg-3' }\end{array}$ & {$[31]$} \\
\hline IS6770 & $\begin{array}{l}\text { Forward: 5'-gatgttgtccgttgtaattgg-3' } \\
\text { Reverse: } 5^{\prime} \text {-ccacatttcttgcgtgtcc-3' }\end{array}$ & [7] \\
\hline
\end{tabular}
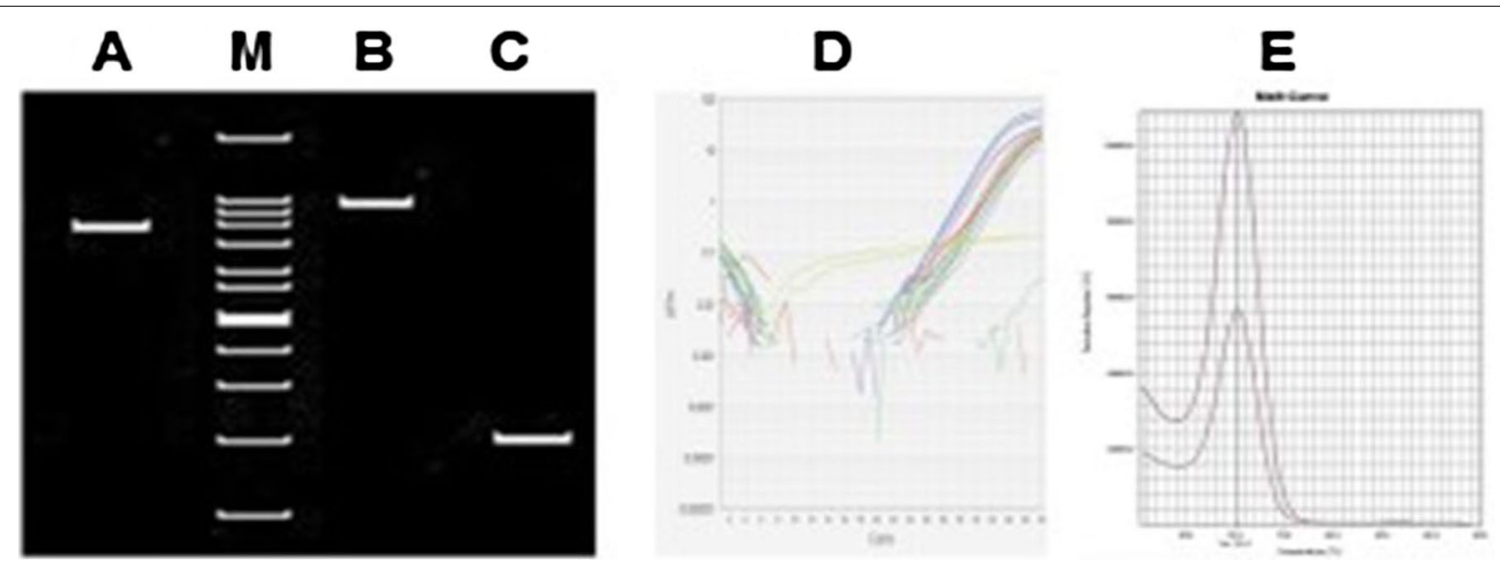

Fig. 1 PCR analysis of E. faecalis cps types [3] (left) and qPCR to identify the presence of IS6770 in cps locus of unencapsulated E. faecalis cps2 genome [7]. A E. faecalis cps1 (950 bp), M DNA marker, B E. faecalis cps2 (1098 bp), and C E. faecalis cps5 (199 bp). D and E are representative amplified $\mathrm{QPCR}$ and its melting peaks, respectively 


\section{Results}

Infection capacity among the three strains

Enterococcus faecalis strains were tested for their capacity to infect MG-63 cells. Overall, E. faecalis strains exhibit a similar adhesion ability to MG-63 cells, and the morphology of infected cells was relatively unchanged during the $3 \mathrm{~h}$ time period (Fig. 2). However, the ability of unencapsulated strain to persist in MG-63 cells was impaired, at least for $12 \mathrm{~h}$, compared to the other strains tested $(\mathrm{p}<0.05)$. At this time point, the intracellular bacteria appear to alter MG-63 cell morphology (Fig. 2).

\section{Different effects of $E$. faecalis strains tested on the} expression of TLR-2, II-1 $\beta$, and iNOS in MG-63 cells

We further determined whether the capacity of the bacterium tested in triggering osteoblast immune response took place through the regulation of certain innate immunity-related genes (TLR2, IL-1 $\beta$, and $i N O S)$. As shown in Fig. 3 , at $3 \mathrm{~h}$ co-cultured, no significant difference was observed in the expression level of TLR2 mRNA. In contrast, after the $12 \mathrm{~h}$ time point, the expression of TLR2 mRNA was increased compared to control (cultured cells without added bacterium), by approximately threefold and sevenfold higher in MG-63 cells co-cultured with encapsulated or reference strain and unencapsulated strains, respectively. Our data also showed an increase in IL-1 $\beta$ mRNA transcription throughout the observation periods ( 3 and $12 \mathrm{~h}$ ). On the contrary, the iNOS mRNA expression was only measured after $12 \mathrm{~h}$ period, where the internalized unencapsulated strain significantly reduced the transcription level of iNOS mRNA, compared to other tested strains (Fig. 4 a, b).

\section{Discussion}

Enterococcus faecalis has been described as a periapical lesion-related species post endodontic treatment [12, 13]. In this in vitro study, the two E. faecalis isolates used were serotype $\mathrm{C}$, genotype2. They possess the cps2 genes, but the insertion sequence (IS6770) affects translation of

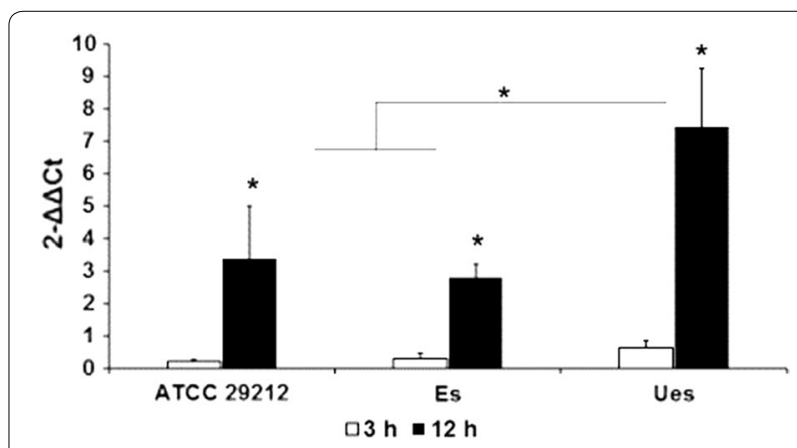

Fig. 3 Analysis of TLR2 mRNA expression in MG-63 cells after infected by E. faecalis ATCC 29212, encapsulated (Es), and uencapsulated (Ues) strains. Expression of TLR2 mRNA was determined by qPR at 3 and $12 \mathrm{~h}$ time points, and normalized to housekeeping gene, GDPH. ${ }^{*} p<0.05$

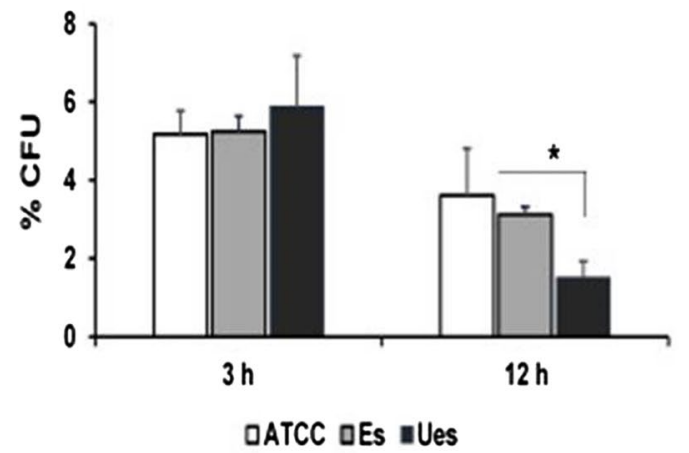

QATCC DEs $\amalg$ Ues
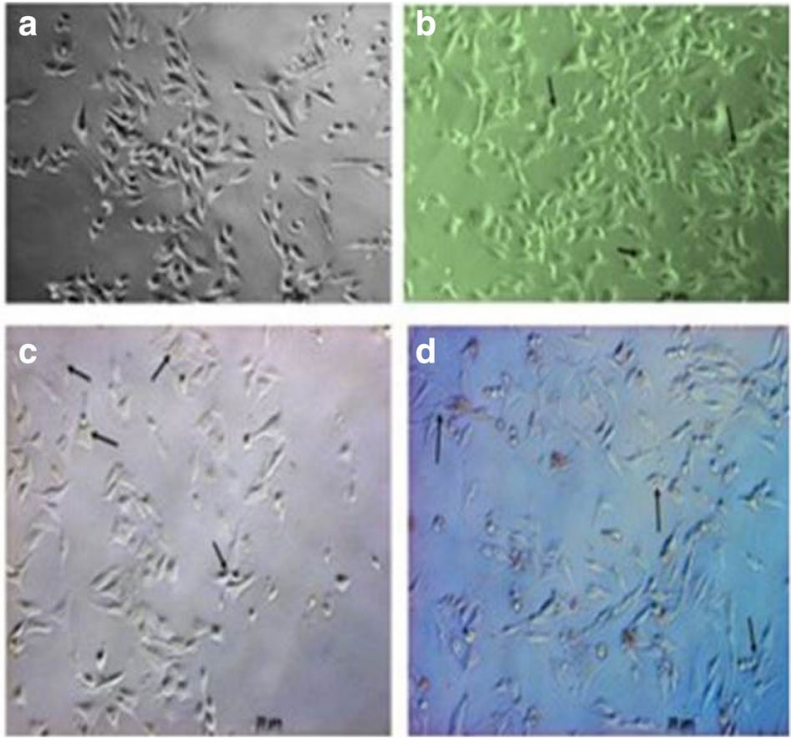

Fig. 2 Infection MG-63 cells by tested E. faecalis cps 2 oral isolates. The binding capacity of encapsulated and unencapsulated strains was comparable after $3 \mathrm{~h}$, but viable inside the cells at least $12 \mathrm{~h}$ post infection as assessed by CFU. ${ }^{*} p<0.05$. The right panel shows the cells that was treated with each E. faecalis strain at $\mathrm{MOI}$ of 1000 for 3 and $12 \mathrm{~h}$ and visualized by using light microscopic images at $\times 400$ magnification. Bar $20 \mu \mathrm{m}$. a Control uninfected cells. b Adhesion phase (3 h). c and $\mathbf{d}$ are cells infected with encapsulated and unencapsulated E. faecalis cps2, respectively. The arrows show adhered and internalized bacteria 
some of the capsule genes and synthesis of the polysaccharide [7]. To answer whether the same serotype $C$ of $E$. faecalis, which displays significant variation in CPS locus may affect their phenotype properties in bacteria-bone cells interaction, we infected osteoblastic MG-63 cells with each oral isolate of E. faecalis cps2, and compared the amounts of adherent and internalized bacteria recovered after 3 and $12 \mathrm{~h}$ time periods.

When tested individually, all E. faecalis strains were attached on MG-63 cell during adhesion phase (3 h) in a similar level. This result indicates that the binding capacity is not strains dependent. It seems that the bacteria retained their capacity to grow as biofilms [6], and subsequently promoted their adherence [14] which is required in the initial step of E. faecalis to infect its host cells [15]. Although CPS has a role in modulating the interaction between bacteria and their host cells [10, 16], we assumed that the expression of CPS in E. faecalis cps2 does not have a crucial role in the adherence process. However, since the capsule is protective [4], it may interfere with the cell sensing of pathogens that avoid the release of pathogen-associated molecular patterns (PAMPs) signals. On the contrary, the unencapsulated $E$. faecalis cps2 needs to protect itself from the cell defense mechanism. As shown in this study, although the number was lower, the bacterium was still viable after $12 \mathrm{~h}$ time period (Fig. 2). The result of this experiment may suggest that the survival of the unencapsulated E. faecalis cps2 within bone-cells is crucial, as it reflects the tolerance response of cells to the bacterium and the interaction between them with low spread and slower growth.

To evaluate whether invasive potential differences between all the tested bacteria to cause varied stimulation effects on proinflammatory response, we further compared the expression level of TLR-2, Il- $1 \beta$, and iNOS mRNAs during bacterial infection the MG-63 cells. The
qPCR result demonstrated that the inflammatory effect by $E$. faecalis cps 2 was in general a time dependent. When adhesion phase $(3 \mathrm{~h})$ in host-bacteria interactions was evaluated, all tested E. faecalis strains showed a similar level in up-regulation of the expression of TLR2 mRNA. Interestingly, when the encapsulated strain persisted for $12 \mathrm{~h}$ in MG-63 cells, the cells cannot mount a TLR-2 response, as the bacterium might be hidden by the capsule. In contrast, the unencapsulated strain produces a higher induction of TLR2 gene. In addition, the immune response of cells as shown by IL- $1 \beta$ gene was highly induced, even at $3 \mathrm{~h}$ (Figs. 3, 4a). This observation suggests that although the unencapsulated strain has a low capacity to invade osteoblast cells, it is still implicated as a pre-requisite for inflammatory bone-cells response by TLR2 activation in osteoblast [17]. This finding may explain the variations in CPS phenotype between isolates of the same serotype $\mathrm{C}$, indicating that factors other than CPS, such as PAMPs, also affect the bacteria invasiveness [18, 19].

According to literature, up-regulated TLR2 initiates a NF-kB signaling cascade that results in a production of proinflammatory cytokines [20, 21]. This study showed that bacterial adhesion per se, shown by either tested E. faecalis strains, could be a sufficient stimulus for the expression of IL- $1 \beta$ mRNA, a potent proinflammatory mediator [22]. This is because the expression of IL-1 $\beta$ mRNA in MG-63 cells, by each tested bacterium, was initiated at adhesion time period $(3 \mathrm{~h})$ and continued to increase until $12 \mathrm{~h}$ post infection (Fig. 4a). Surprisingly, although the IL-1 $\beta$ expression was strongly upregulated by the invading unencapsulated $E$. faecalis cps2, the iNOS mRNA was weakly expressed. If the transcription levels were positively associated with protein production, the current study might suggest that the unencapsulated E. faecalis cps2 strains are not a sufficient stimulator for
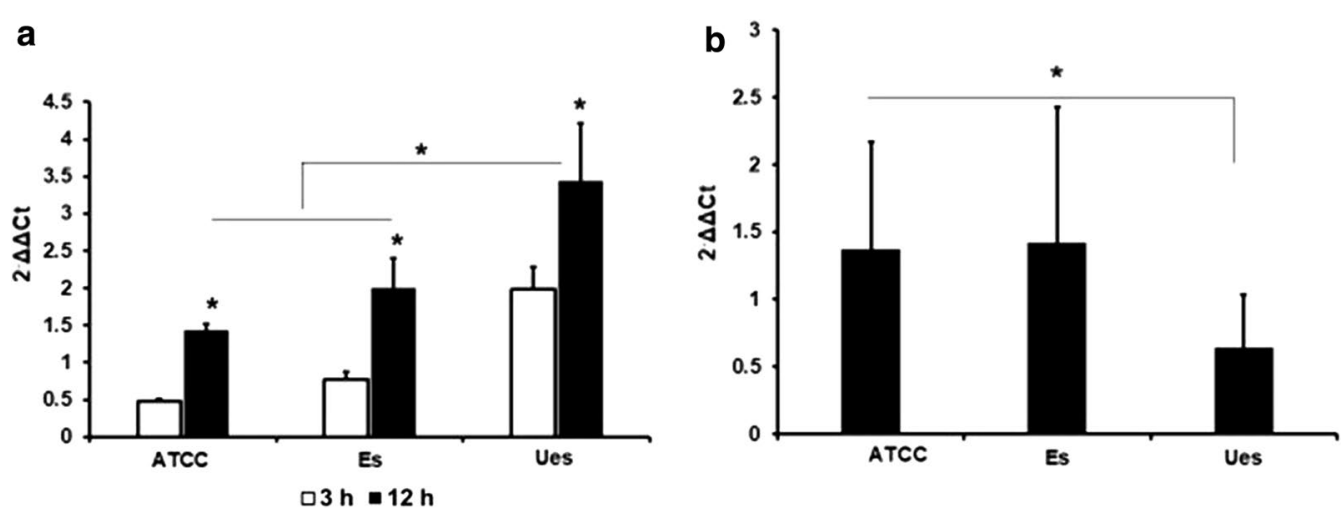

Fig. 4 Measurement of IL-1 $\beta$ and iNOS mRNAs expression in infected MG-63 cells. Level of IL-1 $\beta$ mRNA increased after $3 \mathrm{~h}$ and remained elicite after $12 \mathrm{~h}$ post infection. The unencapsulated (Ues) strain showed a stronger stimulator for IL-1 $\beta$ mRNA expression (a), but weakly inducer for iNOS mRNA expression, compared to encapsulated (Es) and ATCC strains, respectively (b). The asterisks indicate a significant difference 
iNOS production as proinflammatory-related enzyme by MG-63 cell lines.

As reported previously, activation of iNOS pathway by cytokines stimulates nitric oxide $(\mathrm{NO})$ production. NO is an important antimicrobial that play is a major role in innate defense mechanism of host cells [23], to pathogens. This study indicates that low level of NO may imply a lower antibacterial activity for different $E$. faecalis strains.

Some studies report the role of NO in inhibiting bone resorption, thus enhancing osteoblast function [24, 25]. However, other studies have shown a controversial result, as $\mathrm{NO}$ enhances bone resorption induced by cytokines $[26,27]$. Our experiment showed that the very low level of induction of iNOS may result in low level of NO produced by MG-63 cells. This may imply a lower antibacterial activity for unencapsulated E. faecalis cps2 strain. However, since we studied only the mRNA expression of IL-1 $\beta$ gene, there may be other genes which induce discrepant expression iNOS mRNA values showed by different $E$. faecalis cps2 phenotypes. In addition, this study does not imply that the unencapsulated $E$. faecalis cps2 is not a virulent strain, but the lack of iNOS mRNA induction may be an indication of the tolerance immune response of osteoblast-like cells towards the internalized bacterium (unencapsulated E. faecalis cps2 strain).

\section{Conclusion}

Regardless of the mechanism involved, this study demonstrated that adhesion and invasion to osteoblast-like cells do not solely rest on the expression of E. faecalis CPS. Capsule protects the detection of external proteins (PAMPs). In contrast, the absence of CPS, as shown by unencapsulated $E$. faecalis cps2, results in an increased of cells' response. Therefore, this strain must find a way to survive by inducing the cells' tolerance. The very mild iNOS induction may be a strategy to survive and protect the bacterium from host cells response. Thus, unlike the other tested strains, unencapsulated E. faecalis cps2 might not induce NO production. We speculated that the immune system response of MG-63 cells is reduced, and the low NO level is an index of cell tolerance to the bacterium. However, these mechanisms remain to be investigated at molecular level.

\section{Limitations}

- We cannot exclude the possibility that the other unencapsulated E. faecalis strain (cps1 type) that was not included in this study, might show different effect in terms of host inflammation response.

- The encapsulated and unencapsulated E. faecalis cps2 are not isogenic strains. Therefore, we cannot explain what kind of influence of cps2 gene and CPS on the MG-63 cells' response.

\section{Abbreviations}

TLR-2: toll like receptor-2; IL-1ß: Interleukin-1 $\beta$; iNOS: inducible nitric oxide synthase; NO: nitric oxide; ATCC: American type culture collection; CFU: colony forming unit; DMEM: Dulbecco's modified Eagles medium; IS6770: insertion sequence 6770 .

\section{Authors' contributions}

BMB carried out the conception, design of the study, qPCR analysis, and drafted the manuspcript. EWB participated in the cell culture, statistical analysis and reviewed and revised the manuscript. Both authors read and approved the final manuscript.

\begin{abstract}
Acknowledgements
The authors acknowledge Prof. Sutatip Kamolmatyakul, Prince of Songkla University, Thailand for kindly donating the MG-63 cells. We acknowledge Maysaroh and Desy for their assistance in laboratory works. We also express our thanks for Samira Husen Alamudi, research fellow Singapore Bioimaging Consortium (SBIC): Agency for Science Technology and Research (A*STAR) for proofreading this article.
\end{abstract}

\section{Competing interests}

The authors declare that they have no competing interests.

\section{Availability of data and materials}

The data set supporting the conclusions of this study is included within the article.

\section{Consent for publication}

Not applicable.

Ethics approval and consent to participate

Not applicable.

\section{Funding}

This study was supported by the grant from Ministry of Research, Technology, and Higher Education (KEMENRISTEKDIKTI) The Republic of Indonesia 2016.

\section{Publisher's Note}

Springer Nature remains neutral with regard to jurisdictional claims in published maps and institutional affiliations.

Received: 2 June 2017 Accepted: 8 August 2017

Published online: 11 August 2017

\section{References}

1. Brook I. The effect of antimicrobial therapy on mixed infections with Bacteroides species. Is eradication of the anaerobes important? J infect. 1991;22:27-35.

2. Park OJ, Kim J, Yang J, Yun CH, Han SH. Enterococcus faecalis inhibits osteoblast differentiation and induces chemokine expression. J Endod. 2015;41:1480-5.

3. McBride SM, Fischetti VA, Leblanc DJ, Moellering RC Jr, Gilmore MS. Genetic diversity among Enterococcus faecalis. PLoS ONE. 2007;2:e582.

4. Thurlow LR, Thomas VC, Fleming SD, Hancock LE. Enterococcus faecalis capsular polysaccharide serotypes $C$ and $D$ and their contributions to host innate immune evasion. Infect Immun. 2009;77:5551-7.

5. Pinheiro ET, Penas PP, Endo M, Gomes BP, Mayer MP. Capsule locus polymorphism among distinct lineages of Enterococcus faecalis isolated from canals of root-filled teeth with periapical lesions. J Endod. 2012;38:58-61.

6. Bachtiar EW, Bachtiar BM, Dewiyani S, Surono Akbar SM. Enterococcus faecalis with capsule polysaccharides type 2 and biofilm-forming capacity in Indonesians requiring endodontic treatment. J Invest Clin Dent. 2015;6:197-205.

7. Gaspar FB, Montero N, Akary E, Teixeira N, Matos R, Gonzalez-Zorn B, Barreto Crespo MT, Serror P, Silva Lopes Mde F. Incongruence between 
the cps type 2 genotype and host-related phenotypes of an Enterococcus faecalis food isolate. Int J Food Microbiol. 2012;158:120-5.

8. Bachtiar EW, Dewiyani S, Akbar SMS, Bachtiar BM. Inhibition of Candida albicans biofilm development by unencapsulated Enterococcus faecalis cps2. J Dent Sci. 2016;11(3):323-30.

9. Gomes BP, Montagner F, Jacinto RC, Pinheiro ET, Zaia AA, Ferraz CC, Souza-Filho FJ. Gemella morbillorum in primary and secondary/persistent endodontic infections. Oral Surg Oral Med Oral Pathol Oral Radiol Endod. 2008;105:519-25.

10. Bachtiar BM, Coloe PJ, Fry BN. Knockout mutagenesis of the kpsE gene of Campylobacter jejuni 81116 and its involvement in bacterium-host interactions. FEMS Immunol Med Microbiol. 2007;49:149-54.

11. Livak KJ, Schmittgen TD. Analysis of relative gene expression data using real-time quantitative PCR and the 2 ( - Delta Delta $C(T)$ ) method. Methods. 2001;25:402-8.

12. Rocas IN, Siqueira JF Jr, Santos KR. Association of Enterococcus faecalis with different forms of periradicular diseases. J Endod. 2004;30:315-20.

13. Zhu X, Wang Q, Zhang C, Cheung GS, Shen Y. Prevalence, phenotype, and genotype of Enterococcus faecalis isolated from saliva and root canals in patients with persistent apical periodontitis. J Endod. 2010;36:1950-5.

14. Gotz F. Staphylococcus and biofilms. Mol Microbiol. 2002;43:1367-78.

15. Elhadidy M, Zahran E. Biofilm mediates Enterococcus faecalis adhesion, invasion and survival into bovine mammary epithelial cells. Lett Appl Microbiol. 2014;58:248-54.

16. Llobet E, Tomas JM, Bengoechea JA. Capsule polysaccharide is a bacterial decoy for antimicrobial peptides. Microbiology. 2008;154:3877-86.

17. Takeda K, Kaisho T, Akira S. Toll-like receptors. Annu Rev Immunol. 2003;21:335-76.

18. Medzhitov R, Janeway CA Jr. Decoding the patterns of self and nonself by the innate immune system. Science. 2002;296:298-300.

19. Baik JE, Ryu YH, Han JY, Im J, Kum KY, Yun CH, Lee K, Han SH. Lipoteichoic acid partially contributes to the inflammatory responses to Enterococcus faecalis. J Endod. 2008;34:975-82.

20. Akira S, Uematsu S, Takeuchi O. Pathogen recognition and innate immunity. Cell. 2006;124:783-801.
21. Brandt KJ, Fickentscher C, Kruithof EK, de Moerloose P. TLR2 ligands induce NF-kappaB activation from endosomal compartments of human monocytes. PLoS ONE. 2013;8:e80743.

22. Dinarello CA. Interleukin-1, interleukin-1 receptors and interleukin-1 receptor antagonist. Int Rev Immunol. 1998;16:457-99.

23. Vazquez-Torres A, Stevanin T, Jones-Carson J, Castor M, Read RC, Fang FC. Analysis of nitric oxide-dependent antimicrobial actions in macrophages and mice. Methods Enzymol. 2008;437:521-38.

24. Maclntyre I, Zaidi M, Alam AS, Datta HK, Moonga BS, Lidbury PS, Hecker $M$, Vane JR. Osteoclastic inhibition: an action of nitric oxide not mediated by cyclic GMP. Proc Natl Acad Sci. 1991;88:2936-40.

25. Fan X, Roy E, Zhu L, Murphy TC, Ackert-Bicknell C, Hart CM, Rosen C, Nanes MS, Rubin J. Nitric oxide regulates receptor activator of nuclear factor-kappaB ligand and osteoprotegerin expression in bone marrow stromal cells. Endocrinology. 2004;145:751-9.

26. Brandi ML, Hukkanen M, Umeda T, Moradi-Bidhendi N, Bianchi S, Gross SS, Polak JM, Maclntyre I. Bidirectional regulation of osteoclast function by nitric oxide synthase isoforms. Proc Natl Acad Sci. 1995;92:2954-8.

27. Ralston SH, Ho LP, Helfrich MH, Grabowski PS, Johnston PW, Benjamin N. Nitric oxide: a cytokine-induced regulator of bone resorption. J Bone Miner Res. 1995;10:1040-9.

28. Sha Q, Truong-Tran AQ, Plitt JR, Beck LA, Schleimer RP. Activation of airway epithelial cells by toll-like receptor agonists. Am J Respir Cell Mol Biol. 2004;31:358-64.

29. Brydon L, Edwards S, Jia H, Mohamed-Ali V, Zachary I, Martin JF, Steptoe A. Psychological stress activates interleukin-1 beta gene expression in human mononuclear cells. Brain Behav Immun. 2005;19:540-6.

30. Schonfelder G, John M, Hopp H, Fuhr N, van Der Giet M, Paul M. Expression of inducible nitric oxide synthase in placenta of women with gestational diabetes. FASEB J. 1996;10:777-84.

31. Zhang MS, Niu FW, Li K. Proflavin suppresses the growth of human osteosarcoma MG63 cells through apoptosis and autophagy. Oncol Lett. 2015;10:463-8.

\section{Submit your next manuscript to BioMed Central and we will help you at every step:}

- We accept pre-submission inquiries

- Our selector tool helps you to find the most relevant journal

- We provide round the clock customer support

- Convenient online submission

- Thorough peer review

- Inclusion in PubMed and all major indexing services

- Maximum visibility for your research

Submit your manuscript at www.biomedcentral.com/submit
() Biomed Central 